\title{
Numerical and Comparative Study on Pavement RCCP with Finite Element Method
}

\author{
Ali Akbar Mashayekh \\ MA in Civil Engineering, Road \& Transportation, Payam e Noor University International Center of Assaluyeh, \\ Bushehr, Iran \\ Email: mashayekhali52@yahoo.com
}

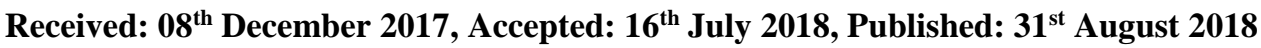

\begin{abstract}
One of the types of materials has been developed for using in pavement of pathway, is roller compacted concrete (RCC). The pavement made of roller concrete can be used for paths with light traffic as well as heavy traffic and the surface of roller concrete in this pavement has characteristic such as more durable, low cost of building and repair and maintenance in surfaces. In this paper, we review the numerical study with finite element method and the impact on two types of pavement namely asphalt and RCC and in this respect, we have been made two models in Ansys software and finally, we will compare the results. This research so far, has been attracted by few people in numerical calculation. In the end, the author, due to the results, has been identified the pavement of roller concrete is more suitable and so, it has been suggested further reviews.
\end{abstract}

Keywords: Pavement, Surface of Roller Concrete, Finite Element Method, Asphalt Pavement

\section{Introduction}

Transportation network of each country is considered as the life of that country and the most massive national capital. In order to have a necessary performance, it is necessary for all elements to play their role well. The airports, passengers and freight terminals, ports and roads could have been considered as the basic elements of this network $[1,11]$.

Unfortunately, in our country, Iran, because of shortage and expensive cement while cheapness and abundance of Bitumen and Gasoline with facility of implement for all years of reconstruction, it has been caused to employ only bitumen in practice, instead of correct and appropriate use of three main elements of pavement. But actually, the pavement without using the concrete and gravel (broken or shaped) is incomplete and inefficient [2,15]. Now, the result is that, we observe a variety of shortcomings on all roads and urban and suburban passages [13].

One of the types of material has been developed for decades is the roller compacted concrete (RCC) [7]. The pavement made of RCC could be used in paths with heavy and light traffic and the surface of RCC in this pavement has some characteristics such as high durability, low cost to build and low level of repair and maintenance [1]. In this research, it has been examined the characteristics of concrete and the application of it in pavement of paths, has been evaluated. Due to study, it has been considered that the pavement of roller compacted concrete compare with flexible pavements that is common in Iran, has lower cost and one can use the cement materials such as fly ash and micro silica in making roller compacted concrete which has been commonly used in concrete. Also, the breakdowns on the pavement of roller compacted concrete compare with flexible pavement specially, for paths with heavy traffic are very low [6].

\section{Background}

Making the pavement of roller compacted concrete has been considered as a modern method in the direction of development of materials like stabilized soil with cement or cement-treated base (CTB )which has been used as a subbase and base in design and building of pavements for long time. This primary application of roller compacted concrete has been done in many countries before the First World War [9]. Canadian engineers in British Columbia State, begin to use the aggregate with high cement in order to create the layers of base with higher quality. Next step. It has been considered the pavement of roller compacted concrete as a complete pavement and without any needs of cover layer [10]. First use of roller concrete compact pavement was in building an area for wood and timber factories with heavy loading in Vancouver in 1970. The performance of roller compacted concrete pavement under heavy loading and severe wear was successful. Since, then roller concrete pavement for building pavement of industrial areas has been widely used in Canada [12]. First sample about application of roller compacted concrete pavement in roads with light traffic in Spain in 1970 and the first application of it was the successful building in road with test access in American Army Student Station in Mississippi in 1975. But, first real and important application of RCCP in America, construction of a large parking lot for tanks and heavy military vehicles in hood base in Texas in 1984. After this successful application, a significant number of pavement has been performed for heavy loads by public, military sector and private sector. These applications has been 
included Heavy military vehicles parking lot, ports and the terminals of container load exchange terminals [18].

The roller compacted concrete is mix of cement concrete with zero slump which is distributed by conventional machines in asphalt concrete and it is compacted by metal rollers and vibrated rollers. This concrete is used in dams and pavement of path. RCC is used as a substitution for clay. The characteristics of mix and the most engineering characteristics RCC is similar to conventional concrete. the roller concrete that is applied to pavement, is a developing technology. About two decades, several pavement projects has been implemented in USA, countries like France, Spain, German, Australia and India and Japan with RCC and the application of it is developing as well [17].

\section{The Reasons of Expanding}

The reasons of expanding use of it in pavement can be stated as follow $[2,14]$ :

- There is no need any device and tools for building and it is not be able to implement by conventional machine for asphalt pavement.

- It is caused to increase the speed of implementation and thus economical saving compare with other pavements (nearly $30 \%$ off compare with concrete pavement).

- Usually there is no need dowel in slits and steel reinforcement of structures.

- Because of strength structure after compaction, it is allowed to pass the traffic earlier than other concrete pavements

- Low consume of cement in RCC than other concrete pavements

- RCC technology is used for path, the coal warehouse, the Warehouse of timber categories, port areas, the areas with heavy traffic, Stabilizing steep embankments or dams, dry sludge ponds or lagoon with effluent and manual portable platforms. The efficiency of concrete is improved by fly ash and it is caused to improve RCCP behavior against crack.

Disadvantages and Problems in Application of Roller Compacted Concrete Pavement

The application of RCC has problems and disadvantages that can be stated as follows [2,14]:

- In paths with heavy traffic, it is difficult to obtain the proper surface texture for preventing slippage

- Leveling surface of RCCP is difficult

- Due to desired performance RCC to changes of necessary humidity for achieving the enough compaction is sensitive so, it needs to exact implementation and controlling in time of building.
- Inadequate data related to long term performance is other effective factor not using in some countries

Introduction of Finite Element Method

This method is a numerical analysis which can be used for solving several and various problems in static, dynamic, linear and nonlinear like stress analysis. The roots of This method come back to 1900, practically, this method enter into engineering discussions specially mechanical and civil engineering in classic. For the first time, this term was used to solve the 2D elasticity problems by Clough in 1960 . However, the first person who used this method was Courant in 1943 [5].

Building and Networking of Engineering Model

After building the element engineering model, real constant and the type of suitable consumer materials is allocated to element engineering model and it is used the optional networking or drawing for meshing the engineering model. Generally, the networking of different elements must conform to creating nodes until they transfer the force after connecting together. (Integrated structure is created) $[6,7]$.

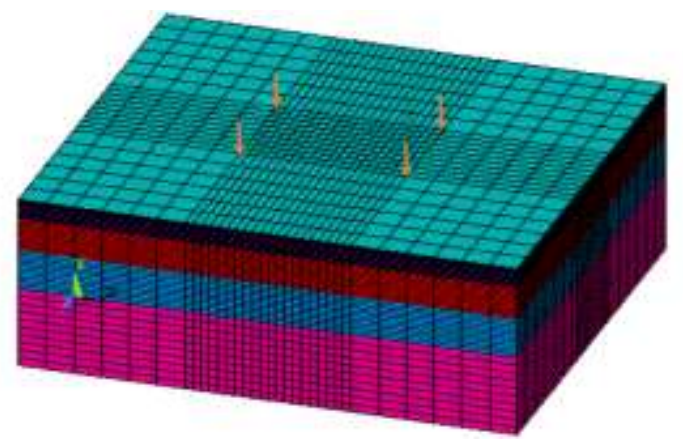

Fig 1: Sample Modeling and its Networking

\section{The Validity of Modeling}

In order to achieve confidence from the results of Analysis, it has been used the experimental model and It has been compared the results of it with finite element model. Experimental sample has been reviewed by author.

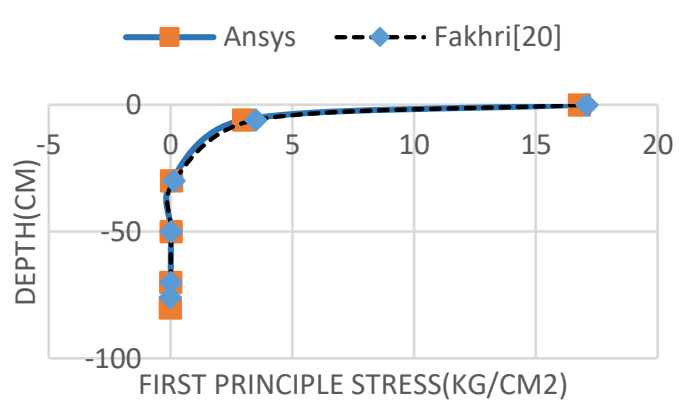

Graph 1: The Comparison between the Results of Model and Finite Element 


\section{Numerical modeling:}

Due to reliability of modeling in previous chapter, we have been reviewed the impact on the type of asphalt pavement and roller compacted concrete. We have been named them according to table (1) for better identifying models.

\begin{tabular}{|l|l|l|}
\hline $\begin{array}{l}\text { Name of } \\
\text { model }\end{array}$ & $\begin{array}{l}\text { The type of } \\
\text { pavement }\end{array}$ & $\begin{array}{l}\text { The thickness of } \\
\text { pavement }\end{array}$ \\
\hline Model 1 & Asphalt & $10 \mathrm{~cm}$ \\
\hline Model 2 & Asphalt & $15 \mathrm{~cm}$ \\
\hline Model 4 & Roller concrete & $10 \mathrm{~cm}$ \\
\hline Model 5 & Roller concrete & $15 \mathrm{~cm}$ \\
\hline
\end{tabular}

Table (1): The Characteristics of Intersections in Models in this Research

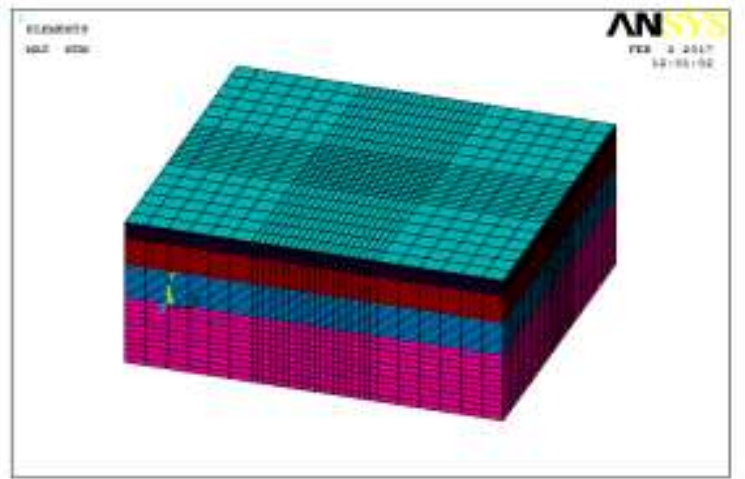

Fig 2: Modeling of Model 1 in Software

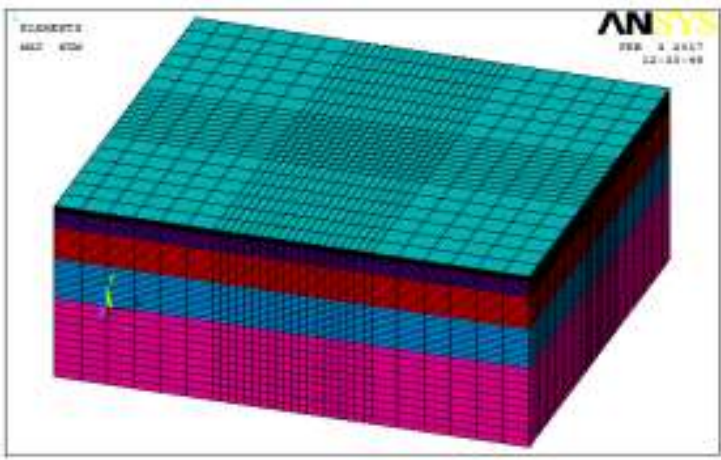

Fig 3: The Modeling of Model 2 in Software The Results of Model M 1

In order to compare the better performance of pavement systems should be compared the parameters like principle tension and movement of under wheels. Due to existing parameters in table 2 is the most important influential parameters on the performance of pavement system. Thus, we have been calculated the parameters for each model.

\begin{tabular}{|c|c|c|c|}
\hline $\begin{array}{l}\text { Modal's } \\
\text { name }\end{array}$ & $\begin{array}{l}\text { Vertical } \\
\text { movement of } \\
\text { under wheels }\end{array}$ & $\begin{array}{l}\text { Maximum } \\
\text { stress in } \\
\text { asphalt layer }\end{array}$ & $\begin{array}{l}\text { Maximum } \\
\text { stress for } \\
\text { basic layer }\end{array}$ \\
\hline M 1 & $0.06 \mathrm{~mm}$ & $11.2 \mathrm{~kg} / \mathrm{cm}^{2}$ & $4.09 \mathrm{~kg} / \mathrm{cm}^{2}$ \\
\hline
\end{tabular}

Table 2: Analysis Results of Model M1

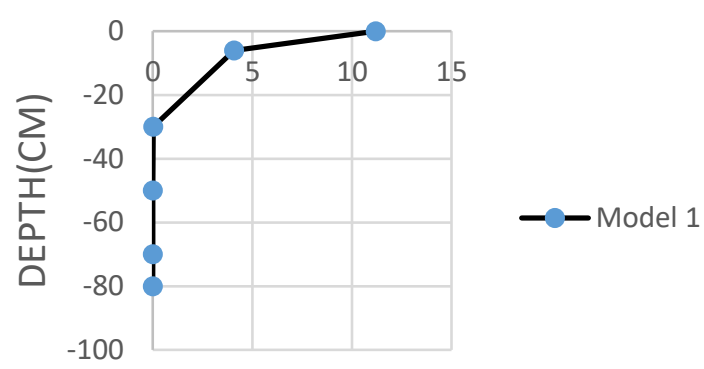

FIRST PRINCIPLE STRESS(KG/CM2)

Chart 2: Stress-Depth of Model M1

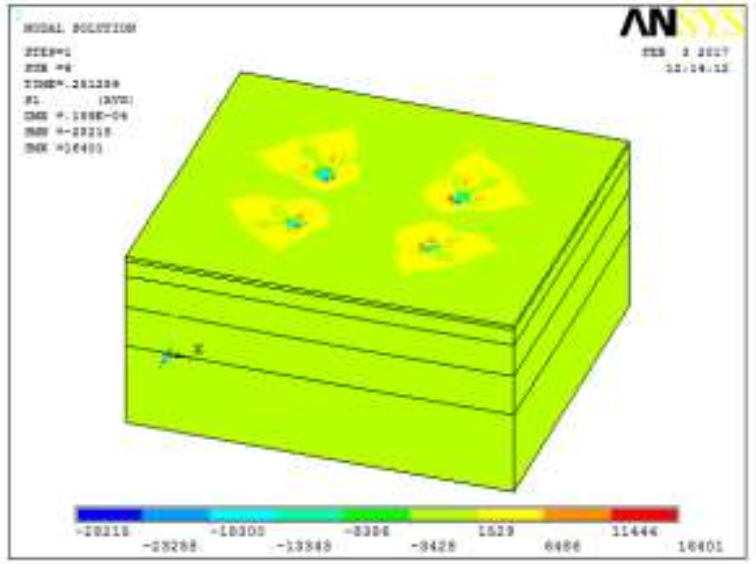

Fig 4: Contour of Principle Stresses in Model M1 The Results of Model M 2:

In order to compare the better performance of pavement systems should be compared the parameters like principle tension and movement under wheels. Due to existing parameters in table 3 is the most important influential parameters on the performance of pavement system. Thus, we have been calculated the parameters for each model.

\begin{tabular}{|l|l|l|l|}
$\begin{array}{l}\text { Modal's } \\
\text { name }\end{array}$ & $\begin{array}{l}\text { Vertical } \\
\text { movement of } \\
\text { under wheels }\end{array}$ & $\begin{array}{l}\text { Maximum } \\
\text { stress in } \\
\text { asphalt layer }\end{array}$ & $\begin{array}{l}\text { Maximum } \\
\text { stress for } \\
\text { basic layer }\end{array}$ \\
\hline M 2 & $\mathbf{0 . 0 5} \mathbf{~ m m}$ & $\mathbf{9 . 6} \mathbf{~ k g / \mathbf { c m } ^ { 2 }}$ & $\mathbf{3 . 2} \mathbf{~ k g / \mathbf { c m } ^ { 2 }}$ \\
\hline
\end{tabular}

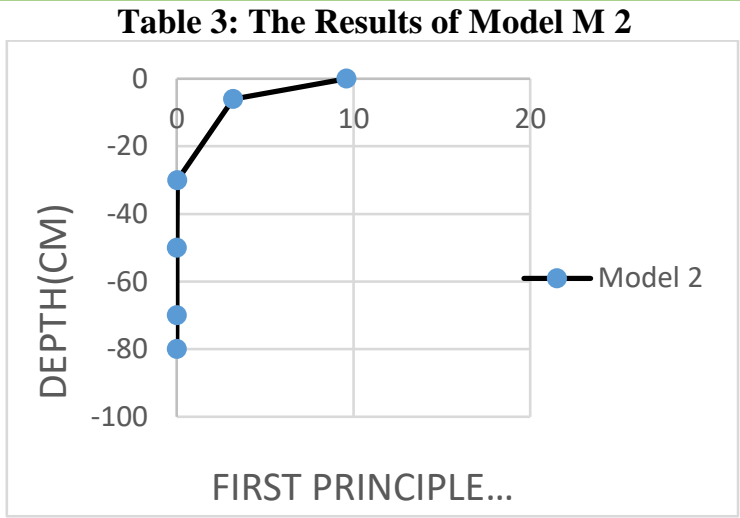

Chart 3: Stress-Depth of Model M 2 


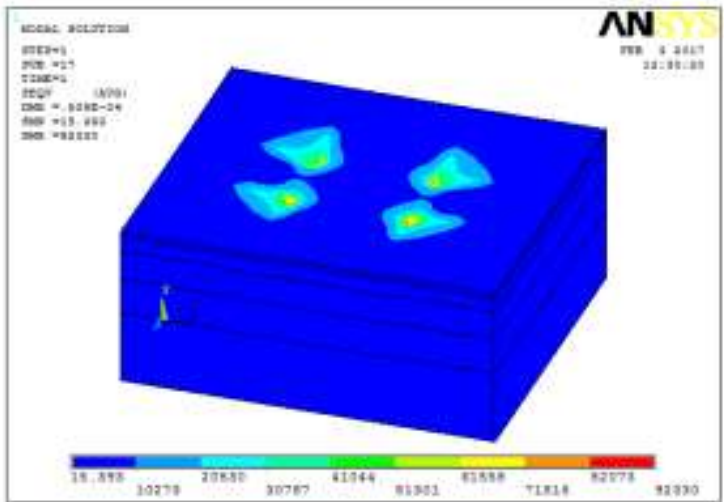

Fig 5: Contours of Principle Tensions in Model 2 The Results of Model M 4:

In order to compare the better performance of pavement systems should be compared the parameters like principle tension and movement of under wheels. Due to existing parameters in table 4 is the most important influential parameters on the performance of pavement system. Thus, we have been calculated the parameters for each model. Due to calculated maximum tension in the layer of roller compacted concrete pavement and the comparison with model cracking concrete is $2.8 \mathrm{Mpa}$ in this study, it is observed that the system has not cracked and it has been presented the appropriate performance.

\begin{tabular}{|l|lll|}
\hline $\begin{array}{l}\text { Model's } \\
\text { name }\end{array}$ & $\begin{array}{l}\text { Vertical } \\
\text { movement } \\
\text { under wheel }\end{array}$ & $\begin{array}{l}\text { Maximum stress } \\
\text { in asphalt layer }\end{array}$ & $\begin{array}{l}\text { Maximum } \\
\text { stress for } \\
\text { basic layer }\end{array}$ \\
\hline M 4 & $\mathbf{0 . 0 4 1} \mathbf{~ m m}$ & $\mathbf{1 1 . 0 7} \mathbf{~ k g / \mathbf { c m } ^ { 2 }}$ & $\mathbf{9 . 8 5} \mathbf{~ k g} / \mathbf{c m}^{\mathbf{2}}$ \\
\hline
\end{tabular}

Table 4: The Analysis Results of Model M 4

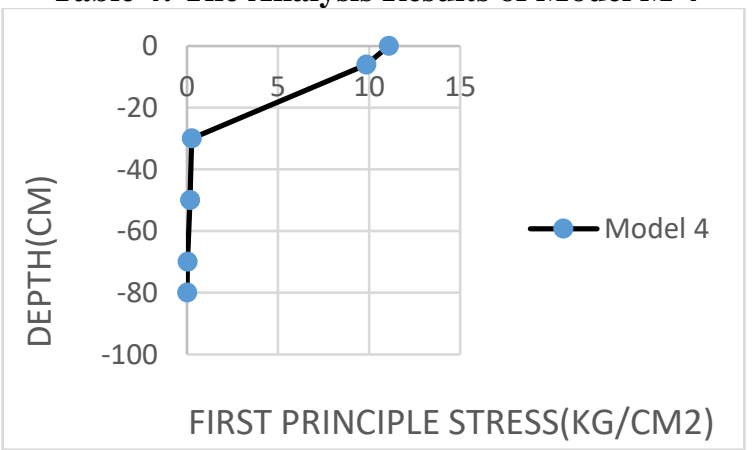

Chart 4: Tension- Depth of Model M 4

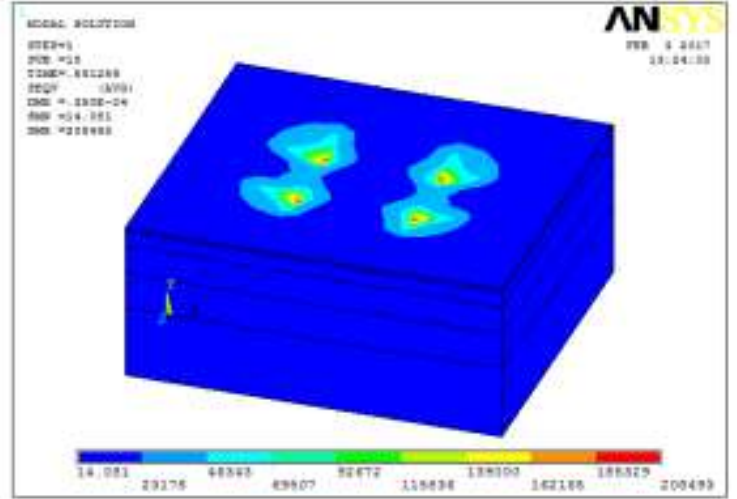

Fig 6: Contour of Principle of Model 4 The Results of Model M 6:

In order to compare the better performance of pavement systems should be compared the parameters like main tension and movement under wheels. Due to existing parameters in table 5-2 is the most important influential parameters on the performance of pavement system. Thus, we -have been calculated the parameters for each model. Due to calculated maximum tension in the layer of roller compacted concrete pavement and the comparison with modulus cracked concrete is $2.8 \mathrm{Mpa}$ in this study, it is observed that the system has not cracked and it has been presented the appropriate performance.

\begin{tabular}{|c|c|c|c|}
\hline $\begin{array}{l}\text { Modal's } \\
\text { name }\end{array}$ & $\begin{array}{l}\text { Vertical } \\
\text { movement of } \\
\text { under wheels }\end{array}$ & $\begin{array}{l}\text { Maximum } \\
\text { stress in } \\
\text { asphalt layer }\end{array}$ & $\begin{array}{l}\text { Maximum } \\
\text { stress for } \\
\text { basic layer }\end{array}$ \\
\hline M 6 & $0.026 \mathrm{~mm}$ & $10.52 \mathrm{~kg} / \mathrm{cm}^{2}$ & $5.34 \mathrm{~kg} / \mathrm{cm}^{2}$ \\
\hline
\end{tabular}

Table 5: The Analysis Results of Model M 6

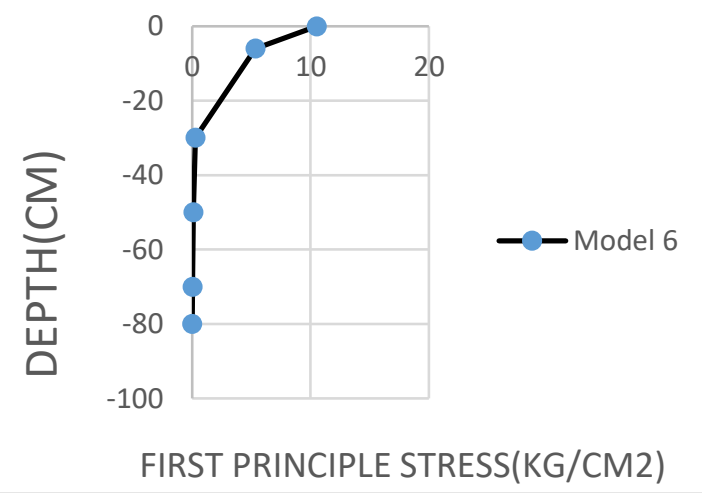

Chart 5: Stress-Depth of Model M6 


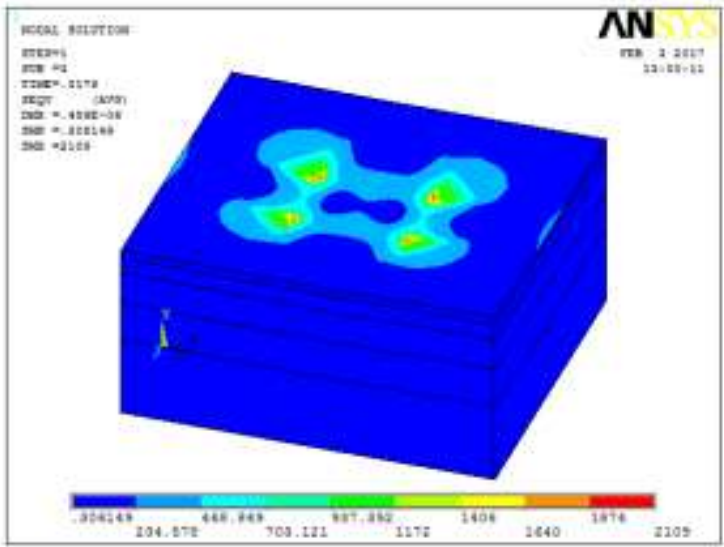

Fig 7: Contour of Principle Stresses in Model 6

The Comparison of Vertical Movement under Load Wheel

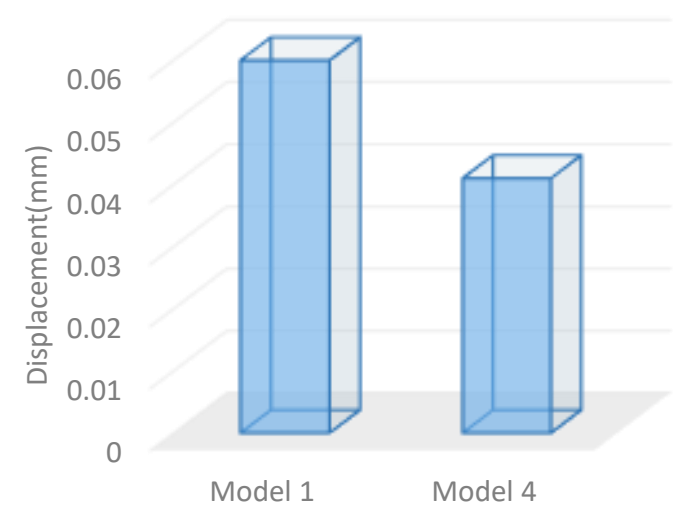

Fig 8: Comparative Bar Chart of Sink under Wheel in Models of Model 1\&4

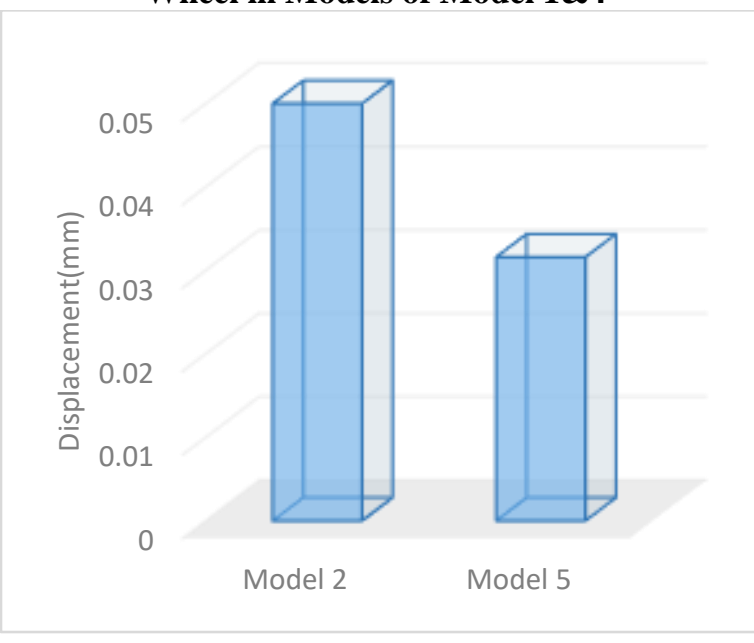

Fig 9: The Comparative Bar Chart of Sink under Wheel in Models of Model 2\&5

\section{Conclusion:}

Through review of the results. It is observed that the type of pavement has incorporated in rate of sink of pavement under load wheel. So that with $10 \mathrm{~cm}$ thickness than asphalt pavement, we observed that approximately decrease of $32 \%$ sink in roller compacted concrete mode. Also, with $15 \mathrm{~cm}$ thickness than asphalt pavement we observed that nearly decrease of $37 \%$ sink. And in pavement with $20 \mathrm{~cm}$ thickness than asphalt pavement we observed the decrease of $35 \%$ sink.

Through review of contour of tensions and the movements from the analysis of finite element, the models of roller compacted concrete has been reviewed. According to the results. It is observed that the maximum tension has been created under wheels, contrary to asphalt mode, it is observed that load distribution has been done correctly and it has prevented from stress concentration tension. This is caused to maintain coherent in pavement systems and under frequently loading- unloading has been less damaged.

Due to calculated values for tension from the layer of roller compacted concrete pavement and comparison with modulus of cracked concrete in this study is equal to $2.8 \mathrm{Mpa}$, it is observed that this system has not been cracked and it has been presented appropriate performance.

According to the results, the author has been identified the roller compacted concrete pavement is more appropriate and has been suggested it for further studies.

\section{References:}

1. Aziz khani, review of mechanical behavior of roller compacted concrete pavement reinforce with metal fiber and polypropylene, the thesis, industrial Isfahan university, 2002

2. Madh khan, the review of resistance of layering the roller compacted concrete by application of cement slurry, technical university press, volume 45, No 6, page 803-858, January 2007

3. Divandary, ghalemansoori, the review of design parameters of slab truck in rail structures, sixth international congress of civil, Semnan, April 2011

4. Aci.(1999)"Report On Roller Compacted Mass Concrete", Aci Manual Of Concrete Practice, Part-I, American Concrete Institute, Committee 207, Farmington Hills, Mi, Usa.

5. Aci.(2001)"Report On Roller Compacted Concrete Pavements", Aci Manual Of Concrete Practice, Part-Iii, American Concrete Institute, Committee 325, Farmington Hills, Mi, Usa.

6. Khalilzadeh, E. And Mokhtarimalekabadi, M. (2012) "Joints In Roller Compacted Concrete Pavements", International Conference On Transport, Environmental And Civil Engineering, Kuala Lumpur, Malaysia. 
7. Koohmishi, M. (2013) "Evaluation Of Application Of Roller Compacted Concrete Versus Asphalt Concrete As Pavement Surface Layer For High Traffic Volume Routes”, Journal Of Basic And Applied Scientific Research, 3(5), Pp. 330-335.

8. Prusinski, J.R. (2013) "Roller Compacted Concrete: A Value-Added Pavement Solution", Cement Council Of Texas, Aia, Provider Number: A090.

9. Nanni, A. "Curing Of Roller Compacted Concrete: Strength Development", Journal Of Transportation Engineering, Vol. 114, No. 6, 1988.

10. Hazaree, Ch., Ceylan,H., Wang, K., "Influences Of Mixture Composition On Properties And Freeze-Thaw Resistance Of Rcc", Construction And Building Materials, Vol. 25, No. 1, Pp. 313319, 2011.

11. Pca. (2012) "Roller Compacted Concrete For Ports: The Port Of Virginia Builds Rcc Pavement For Tough Duty",Www.Cement.Org/Pavements.

12. Banthia, N., Pigeon, M., Marchand, J., and Boisvert, J., "Permeability of Roller Compacted Concrete", Journal of Material in Civil Engineering, V. 4, pp. 27-40, 1992.

13. KS LTAP. (2012) "Experiences with roller compacted concrete in Kansas", Kansas Local Technical Assistance Program, Kansas University Transportation Center.

14. U.S. Army Corps of Engineers (USACE), "Roller compacted Concrete Pavement Design and Construction', Engineer Technical Letter 1110-3475, Department of the army, Washington, D.C., 1995.

15. Huang, Y.H., "Pavement Analysis \& Design", Prentice Hall, New Jersey, 1993, pp.16-17.

16. "Guide for Roller-Compacted Concrete Pavements", Portland Cement Association (PCA), August2010

17. Kagaya, M., Suzuki, T., Kokubun, S. and Tokuda H. (2001) "A study on mix proportions and properties of steel fiber reinforced roller compacted concrete for pavements", JSCE, No. 669/V-50.

18. Hassani, A., Shekarchizade, M. and Akbarnejad, S. (2008) "Properties of roller compacted concrete containing a high-volume and lowvolume non-plastic aggregates for pavements", TRB 1078, National Research Council, Washington, D.C.

19. Fakhri, M., \& Amoosoltani, E. (2017). The effect of Reclaimed Asphalt Pavement and crumb rubber on mechanical properties of Roller Compacted Concrete Pavement. Construction and Building Materials, 137, 470-484.
20. M., Fakhri, Zokaei, M., \& Rahiminezhad, S. (2017). A Parametric Study of Jointed Plain Concrete Pavement Using Finite Element Modeling. Modern Applied Science, 11(11), 75. 